\title{
MET Exon 14 Skipping Alterations in Non-small Cell Lung Carcinoma-Current Understanding and Therapeutic Advances
}

\author{
Rashmi Shah, ${ }^{1,2}$ Deepu Alex, ${ }^{3}$ and Zhaolin $\mathrm{Xu}^{1,2}$ \\ 1. Department of Pathology, Dalhousie University, Halifax, NS, Canada; 2. Department of Anatomical Pathology, Queen Elizabeth II Health Science \\ Centre, Halifax, NS, Canada; 3. Department of Pathology and Laboratory Medicine, BC Cancer, Vancouver, BC, Canada
}

DOI: https://doi.org/10.17925/OHR.2021.16.2.100

\begin{abstract}
A bnormal activation of mesenchymal epithelial transition (MET) receptor tyrosine kinase is associated with oncogenesis. Various underlying mechanisms, including alteration, amplification, gene rearrangement, and exon skipping in the transcript account for abnormal MET signaling. One of the critical alterations in MET leading to non-small cell lung carcinoma (NSCLC) is MET exon 14 (METex14) skipping, a driver mutation, which accounts for approximately 3-4\% of lung adenocarcinoma. METex14 skipping results in the formation of a functionally active and stable truncated receptor lacking the juxtamembrane regulatory domain responsible for MET ubiquitination. Several MET kinase inhibitors have been developed targeting MET receptors, and many are in clinical trials. The US Food and Drug Administration has recently approved capmatinib (TabrectaTw; Novartis, Basel, Switzerland) for the treatment of NSCLC with METex14 skipping alteration. We review the current understanding of the implications of aberrant MET activation in NSCLC harboring METex14 skipping alteration, available diagnostic options, potential therapies in the pipeline, and the future clinical landscape for such alterations.
\end{abstract}

\section{Keywords}

Non-small cell lung cancer, MET exon 14 skipping, METex14, diagnostic method, therapeutic intervention, targeted therapy, MET inhibitors, clinical trials

Disclosures: Rashmi Shah, Deepu Alex, and Zhaolin Xu have no financial or non-financial relationships or activities to declare in relation to this article.

Peer Review: Double-blind peer review.

Compliance with Ethics: This article involves a review of the literature and did not involve any studies with human or animal subjects performed by any of the authors.

Authorship: The named authors meet the International Committee of Medical Journal Editors (ICMJE) criteria for authorship of this manuscript, take responsibility for the integrity of the work as a whole, and have given final approval for the version to be published.

Access: This article is freely accessible at touchONCOLOGY.com (c) Touch Medical Media 2020.

Received: October 14, 2020

Accepted: December 17, 2020

Published Online: December 23, 2020

Citation: Oncology \& Haematology Review. 2020 16(2):100-10

Corresponding Author: Zhaolin Xu, Department of Anatomical Pathology, Queen Elizabeth II Health Science Centre, 5788 University Ave. Rm 734, Halifax B3H 1V8, NS, Canada. E: zhaolin.xu@nshealth.ca

Support: No funding was received in the publication of this article.
Advanced non-small cell lung carcinoma (NSCLC) treatment paradigms have evolved during the past decade. Identification of tumor-specific molecular alteration in cancer driver genes has led to the development of targeted therapies. ${ }^{1-3}$ Most of the tumors harboring such alterations are sensitive to tyrosine kinase inhibitor (TKI) drugs, making such oncogenic drivers promising targets for the development of antitumor therapeutics. ${ }^{4,5}$

MET is a proto-oncogene that can act as an oncogenic driver after certain genomic alterations. It is expressed in many epithelial as well as mesenchymal cells, including hepatocytes, hematopoietic cells, and neuronal cells, and is essential for important biological processes, such as embryonic development and organogenesis. ${ }^{6,7}$ However, mutations and its aberrant activation can promote tumor development and cancer progression by dysregulating downstream signaling pathways.8, Initially, abnormal MET signaling was believed to be the mechanism of resistance acquired by NSCLC tumor cells against certain therapeutics. ${ }^{10-12}$ Further reports demonstrated the role of MET alterations in sustained MET pathway dysregulation, leading to oncogenesis. ${ }^{13-15}$ Clinically, NSCLCS with MET alterations are associated with poor prognosis, and these alterations have been recognized as an important therapeutic target in various cancers, including NSCLC. ${ }^{16-18}$

In this review, we discuss the current understanding of the implications of aberrant MET activation in NSCLC harboring MET exon 14 (METEx14) skipping alteration, available diagnostic options, potential therapies in the pipeline, and the future clinical landscape.

\section{Structure and function of the MET receptor}

MET was first identified in a chemically treated human-osteosarcoma-derived cell line as a transforming gene from a fusion of TPR-MET. ${ }^{19}$ The MET gene is located on chromosome $7 \mathrm{q} 31$ in the human genome, which spans about $125 \mathrm{~kb}$ DNA and contains 21 exons and 20 introns. ${ }^{20} \mathrm{MET}$ is encoded as a precursor, which is modified into a mature protein by proteolytic cleavage between its $\alpha$ and $\beta$ subunits. ${ }^{21} \mathrm{~A}$ mature MET protein is composed of a small $\alpha$ subunit (50 kDa) and a larger $\beta$ (145 kDa) subunit linked together by a disulfide bridge. ${ }^{8}$ The $\alpha$ subunit and a portion of $\beta$ subunit together form the extracellular region of the heterodimer protein, while the remainder of the $\beta$ subunit comprise the transmembrane and intracellular regions (Figure 1A). 
Figure 1: Structure of MET receptor

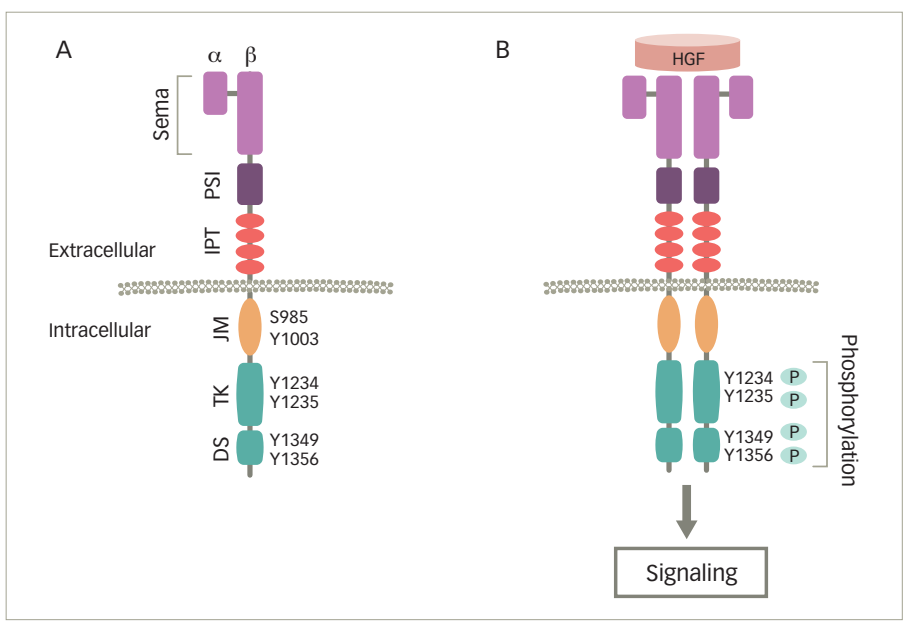

A: Schematic representation of MET receptor and its domain architecture. Important residues in regulatory, catalytic, and docking regions are shown. B: Activation of MET receptor. HGF binding to the $\mathrm{N}$-terminal domain of MET results in its dimerization and autophosphorylation, leading to downstream signaling. Phosphorylation of tyrosine residues in regulatory, catalytic, and docking sites are shown.

$D S=$ docking sites; HGF = hepatocyte growth factor; IPT = immunoglobulins-plexinstranscription factors; $J M=$ juxtamembrane; MET = mesenchymal epithelial transition; PSI = plexins-semaphorins-integrins; Sema = semaphorin domain; TK = tyrosine kinase

The extracellular component of MET contains three domains. N-terminal Sema (Sema-phorin) is the largest domain comprising 500 residues, which encompasses the $\alpha$ and a part of $\beta$ subunits. The domain is essential for the ligand binding, ${ }^{22}$ dimerization, and activation of MET. ${ }^{23,24}$ The Sema domain is followed by the plexins-semaphorins-integrins (PSI) domain, containing four disulphide bonds, which are essential for the proper orientation of the receptor for ligand binding. ${ }^{25}$ The PSI domain is connected to the transmembrane helix of MET through the immunoglobulin-plexinstranscription factor domain. The intracellular portion of the receptor includes a juxtamembrane (JM) domain, a tyrosine kinase (TK) catalytic domain, and a C-terminal multifunctional docking site. ${ }^{22}$ Binding of its ligand, hepatocyte growth factor (HGF), which is also known as scatter factor, is essential for the activation of the kinase activity. ${ }^{26,27}$ HGF is the only MET receptor ligand known so far and binds to the receptor with high affinity. ${ }^{22,28}$

\section{MET signaling and its dysregulation in NSCLC}

HGF binding to MET causes dimerization of the receptor leading to the autophosphorylation of intracellular residues Y1234 and Y1235 in the kinase domain followed by phosphorylation of two additional tyrosine residues, Y1349 and Y1356, in the C-terminal outside of the kinase domain (Figure $1 B$ ). Phosphorylation of the $\mathrm{C}$-terminal residues leads to the formation of the docking site, which is necessary for the engagement of signaling partners. ${ }^{29}$ Subsequently, adapter and effector proteins, such as GRB2 (growth factor receptor bound protein 2), GAB1 (GRB2 associated binding protein 1) and SHC (Src homology 2 domain-containing), bind to the docking site triggering downstream signaling. ${ }^{30-36}$ MET signaling plays a crucial role in executing various cellular functions. ${ }^{37-39}$ To maintain functional balance and cellular integrity, MET activity is regulated through various mechanisms. The active MET receptor can phosphorylate at residue Y1003 in the JM domain, a site for the recruitment of E3-ligase Casitas B-lineage Iymphoma (CBL), and subsequently undergo ubiquitin-mediated lysosomal degradation, leading to the downregulation of MET (Figure 2A).40-42 Additionally, it has been shown that phosphorylation of $\mathbf{S 9 8 5}$ at JM domain acts as a counterbalance to receptor activation, by
Figure 2: MET splicing event involving exon 14 and its consequences to MET stability

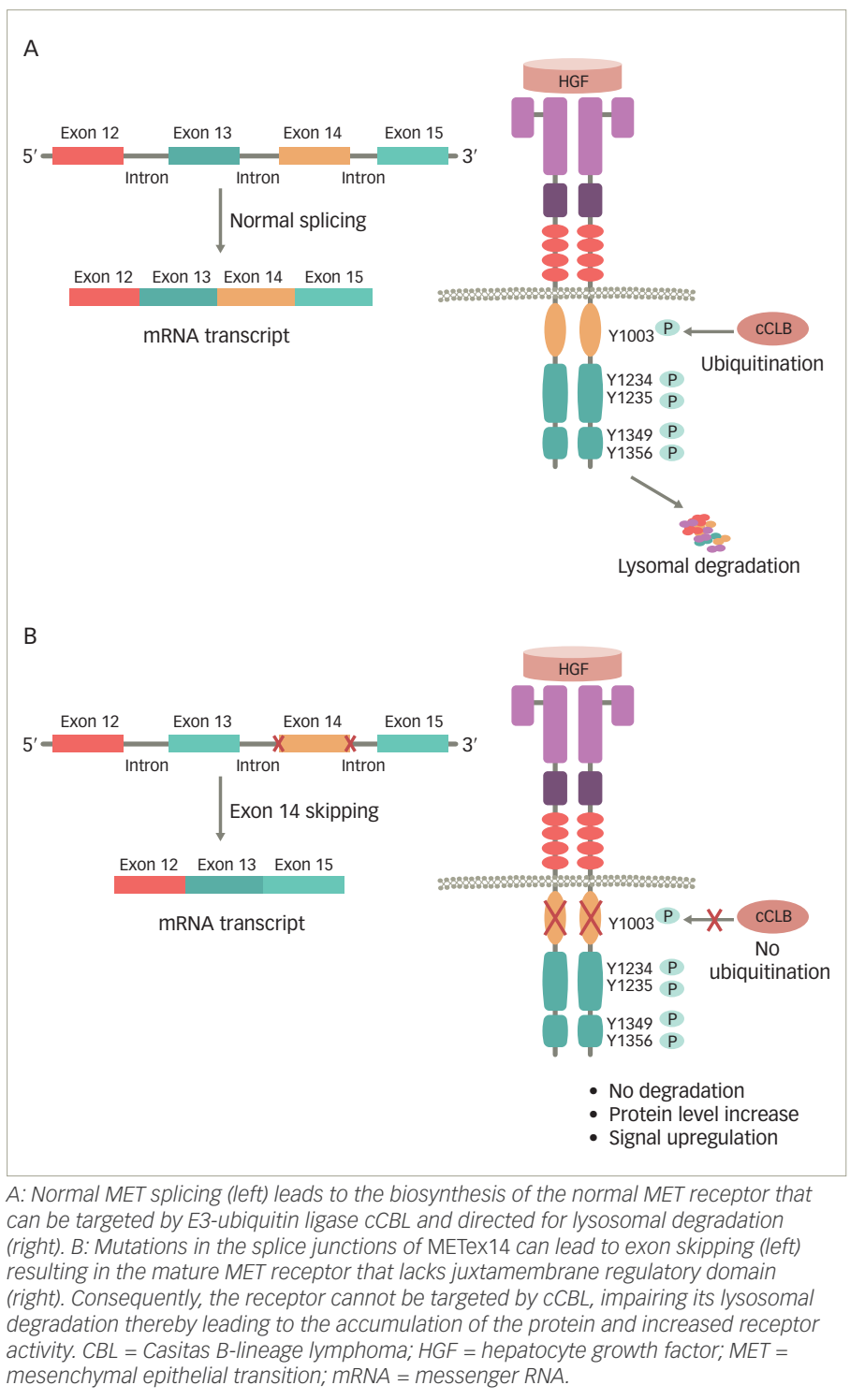

negatively regulating its activity, even in the presence of HGF. ${ }^{43,44}$ Furthermore, proteolytic cleavage of MET by ADAMs (a disintegrin and metalloproteinase) and gamma-secretase may also contribute to the downregulation of MET receptor activity. 45,46

Alterations in MET can result in the dysregulation of MET signaling, which is present in various solid tumors including NSCLC and is associated with tumor progression and metastasis. ${ }^{47-49}$ Gene amplification, rearrangement, and skipping alterations, which lead to the overexpression and impaired degradation of MET, are the major underlying factors of aberrant MET activation. ${ }^{50,51}$ Alteration or deletion of crucial residues in regulatory domain interfere with mechanisms that help to maintain MET receptor turnover leading to its accumulation and hyperactivation. . $^{52-54}$

\section{METex14 skipping alteration in NSCLC}

Skipping of METex14 in NSCLC was first reported in 2005. ${ }^{55}$ Substitutions or deletions at $3^{\prime}$ splice site in intron 13 or the $5^{\prime}$ end splice site of 
Figure 3: Molecular mechanism of MET splicing and exon 14 skipping

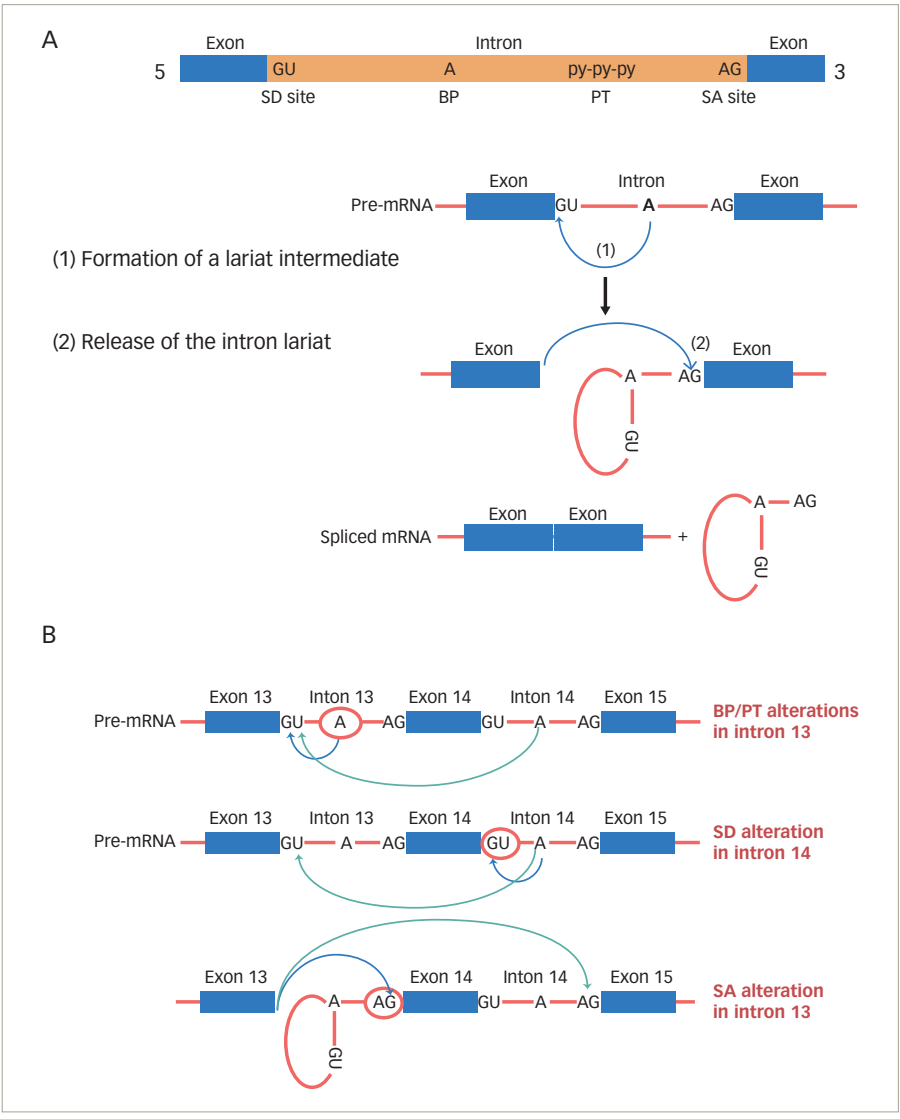

A: Schematic representation pre mRNA splicing mechanism. GU: $5^{\prime}$ splice donor (SD) site, AG: 3' splice acceptor (SA) site, A: branch point (BP) and PY-PY-PY: poly-pyrimidine tract (PT). The SA is flanked upstream by the BP and PT sites, resulting the exclusion of the intron forming of a lariat.

B: Molecular mechanism involved in METex14 alterations. Molecular alterations in intron 13 or 14 involving donor or receptor sites can result in exon 14 skipping.

$B P=$ branch point; $M E T=$ mesenchymal epithelial transition; $S A=$ splice acceptor; $S D=$ splice donor; $P T=$ poly-pyrimidine trace.

intron 14 results in METex14 skipping. ${ }^{56,57}$ This somatic alteration, at or around the splice junction of METex14, leads to the loss of exon 14 in the transcript and synthesis of the MET protein with an in-frame deletion of 47 amino acids in the JM domain (including residue Y1003) ablating the CBL-mediating ubiquitination and degradation of the receptor (Figure 2B). ${ }^{24,58}$ Consequently, METex14 skipping results in increased levels of MET protein, which can drive activation of downstream signaling pathways that promote tumor development. ${ }^{57,59}$

Splicing occurs through two sequential steps involving various parts of the intron. The splice donor site and the splice acceptor site are present at the $5^{\prime}$ and $3^{\prime}$ ends, respectively. The splice acceptor site is flanked upstream by the branch point and poly-pyrimidine tract sites (Figure $3 \mathrm{~A}$ ). First, the branch point nucleotide performs a nucleophilic attack on the first nucleotide of the intron at the splice donor site. This forms an intermediate loop or lariat. Subsequently, the $3^{\prime}$ end of the released exon performs a similar nucleophilic attack on the last nucleotide of the SA thereby fusing the exons and releasing the intron lariat. ${ }^{60,61}$ Most METex14 skipping alterations involve the branch point, poly-pyrimidine tract or splice acceptor site in intron 13 or the splice donor site in intron 14. As shown in Figure $3 B$, these alterations interfere with the splicing mechanism leading to exon 14 skipping.

Interestingly, METex14 skipping alterations are primary oncogenic drivers in NSCLC, as these alterations are most likely to be mutually exclusive to other known oncogenic drivers, such as KRAS, EGFR, ALK, ROS1 or RET ${ }^{57,62,63}$ Approximately $3-4 \%$ of NSCLCs harbor the METex14 alteration (Table 1). ${ }^{18,57,63-68}$ They are associated with some histologic subtypes of NSCLC but are not related to tumor stage. Among the histological subtypes, METex14 skipping alteration is commonly found in sarcomatoid carcinoma (4.9-31\%), ${ }^{69-72}$ adenosquamous carcinoma (4-8\%), ${ }^{18,73,74}$ adenocarcinoma (3-4\%), ${ }^{1,18,57,65,75,76}$ and squamous cell carcinoma (2\%). ${ }^{7,77}$ Also, among adenocarcinomas, the predominant subtypes are acinar (35-52.9\%) or solid subtypes (35.3-53\%). ${ }^{64,70,73,74,77}$ Clinically, METex14 skipping abnormality is found mostly in patients of advanced age. $18,63,68,70,73,74,77,78$

\section{Detection of METex14 skipping alteration}

Immunohistochemical analysis is a routine practice for the detection of MET overexpression. However, this technique on its own cannot specifically confirm METex14 skipping or an underlying alteration. Therefore, DNA- and RNA-based molecular assays are preferred methods for the detection of METEX14 alteration. DNA-based sequencing assay can detect MET alterations such as insertions, deletions, point mutations, or duplications in splice sites, which may cause exon 14 skipping. Identification of such mutational hotspots leading to METex14 skipping alteration are used to predict the possible skipping event. However, METex14 skipping is associated with more than 120 reported sequence variants in splice sites, which makes it challenging to detect these mutations using only DNA-based assays. ${ }^{57.63}$ Therefore, analysis of RNA transcripts allows for the verification of fusion between exons 13 and $15 .{ }^{83}$ In ideal cases, both DNA- and RNAbased assays are used to complement each other for reliable detection of METex14 alterations (Table 1) ${ }^{1.18,63-82}$

Reverse transcription polymerase chain reaction (RT-PCR), quantitative real time RT-PCR, and Sanger sequencing are the routine approaches used for the analysis of mutations and METex14 alteration. ${ }^{18,73}$ mRNA transcript can be reverse transcribed using RT-PCR and corresponding complementary DNA is sequenced using Sanger techniques to verify exon 14 skipping from the sample. However, efficiency of the method relies on the quality of RNA, which is often derived from formalin-fixed paraffin-embedded or frozen tissue. ${ }^{83}$ Sanger sequencing of METex14 and its splice sites is still in routine practice for small scale analysis covering a portion of genomic region, which is performed using the PCR amplicon from genomic DNA covering exon 13 and exon 15, or cDNA from MET transcript. However, the European Society for Medical Oncology (ESMO) guidelines has proposed next-generation sequencing (NGS) and RNA sequencing, if possible, to detect METex14 alteration in its updated guidelines on September 2020. ${ }^{84,85}$

Recently, NGS has become a common diagnostic method to identify METex14 alterations. This high throughput method allows the large-scale analysis of multiple samples in a short time with comprehensive genomic coverage. ${ }^{1,64,86,87}$ The two most popular NGS sequencing panels used for targeted sequence profiling are hybridization capture and ampliconbased sequencing panels. The hybridization capture panel allows more comprehensive profiling for all alteration types, whereas the amplicon- 
Table 1: Prevalence of METex14 skipping alteration and diagnostic method for detection used in various studies

\begin{tabular}{|c|c|c|c|c|c|c|}
\hline Location & $\begin{array}{l}\text { Number of } \\
\text { patients }\end{array}$ & Histology & Diagnostic method & $\begin{array}{l}\text { Median age, } \\
\text { years (range) }\end{array}$ & METex14 alterations & Reference \\
\hline USA & 230 & ADC & WES & $68.5(42-86)$ & $4.3 \%(10 / 230)$ & CGARN $(2014)^{1}$ \\
\hline Korea & 70 & ADC & RT-PCR followed by gDNA sequencing & 65 & $2.9 \%(2 / 70)$ & Park et al. $(2015)^{75}$ \\
\hline Hong- Kong & 154 & $A D C$ & PCR-sanger sequencing & $64.3(28-90)$ & $3.9 \%(6 / 154)$ & Yeung et al. (2015) \\
\hline USA & 36 & PSC & $\begin{array}{l}\text { WES, RT-PCR followed by sanger } \\
\text { sequencing }\end{array}$ & $69.3(38-87)$ & $22.2 \%(8 / 36)$ & Liu et al. $(2015)^{69}$ \\
\hline USA & 54 & NSCLC & $\begin{array}{l}\text { RNA sequencing followed by gDNA } \\
\text { sequencing }\end{array}$ & $75(43-84)$ & $\begin{array}{l}18.5 \%(10 / 54) \text { cohort of WT-EGFR, KRAS, } \\
\text { ALK, ROS1 }\end{array}$ & Heist et al. $(2016)^{79}$ \\
\hline China & 1,296 & NSCLC & NGS, RT-PCR sanger sequencing & $59(41-77)$ & $0.9 \%(12 / 1,296)$ all; $0.9 \%(10 / 1,101)$ of ADC & Liu et al. $(2016)^{80}$ \\
\hline USA & 933 & NSCLC & NGS, confirmation by qRT-PCR & $72.5(59-84)$ & $3.0 \%(28 / 933)$ & Awad et al. (2016)63 \\
\hline Hong Kong & 687 & NSCLC & $\begin{array}{l}\text { PCR followed by sanger sequencing } \\
\text { (using gDNA) }\end{array}$ & 74 & $\begin{array}{l}2.6 \% \text { (18/687) all; } 2.6 \% \text { (10/392) ADC; } 4.8 \% \\
\text { (1/21) ASC; } 31.8 \% \text { (7/22) PSC }\end{array}$ & Tong et al. $(2016)^{18}$ \\
\hline China & 1,770 & NSCLC & QRT-PCR & $66(47-77)$ & $\begin{array}{l}1.3 \%(23 / 1,770) \text { all; } 1.6 \%(21 / 1,305) \text { ADC; } 4.2 \% \\
\text { (2/48) ASC }\end{array}$ & Zheng et al. (2016)73 \\
\hline USA & 11,205 & $\begin{array}{l}\text { Lung } \\
\text { cancers }\end{array}$ & Hybrid capture-based NGS & $73(43-95)$ & $\begin{array}{l}2.7 \%(298 / 11,205) \text { all; } 2.9 \%(205 / 7,140) \text { ADC; } \\
\text { 2.1\% (25/1,206) SCC; } 8.2 \% \text { (8/98) ASC; } 7.5 \% \\
\text { (8/107) PSC }\end{array}$ & Schrock et al. $(2016)^{74}$ \\
\hline USA & 860 & $A D C$ & Hybrid capture-based NGS & - & $3.0 \%(26 / 860)$ & Jordon et al. $(2017)^{81}$ \\
\hline Korea & 795 & NSCLC & QRT-PCR followed by sequencing & $73(55-81)$ & $\begin{array}{l}2.1 \%(17 / 795) \text { ADC; } 37.8 \% \text { (17/45) cohort of } \\
\text { WT-EGFR, KRAS, ALK, ROS1 }\end{array}$ & Lee et al. $(2017)^{64}$ \\
\hline Korea & 102 & ADC, PSC & qRT-PCR & 73 (59-82) & 8.8\% (9/102) ADC; $20.0 \%$ (9/45) PSC & Kwon et al. $(2017)^{70}$ \\
\hline France & 231 & $A D C, P S C$ & $\begin{array}{l}\text { MaSSARRAY iPLEX genotyping } \\
\text { technology, sanger sequencing }\end{array}$ & $61(41-79)$ & $5.3 \%(8 / 150)$ ADC; $5 \%$ (4/81) PSC & Saffroy et al. (2017) \\
\hline Taiwan & 850 & $\begin{array}{l}\text { Lung } \\
\text { cancers }\end{array}$ & RT-PCR followed by sequencing & 77 (36-95) & $\begin{array}{l}\text { 3.3\% (28/850) all; } 4.0 \% \text { (27/668) ADC; } 1.3 \% \\
\text { (1/78) SCC }\end{array}$ & Gow et al. $(2017)^{77}$ \\
\hline China & 77 & PSC & RT-PCR, NGS & $62(37-80)$ & $20.8 \%(16 / 77)$ & Li et al. $(2018)^{82}$ \\
\hline China & 461 & NSCLC & RT-PCR, sanger Sequencing & $60(31-87)$ & $2.0 \%(9 / 461)$ & Qiu et al. $(2018)^{66}$ \\
\hline USA & 3,632 & NSCLC & Hybrid capture-based NGS & - & $3 \%(113 / 3632)$ & Suzawa et al. (2019) ${ }^{67}$ \\
\hline Korea & 414 & NSCLC & $\begin{array}{l}\text { qRT-PCR and/or Sanger sequencing } \\
\text { (followed by hybrid capture-based } \\
\text { NGS in some of the patients) }\end{array}$ & $69(54-80)$ & $\begin{array}{l}\text { 3.14\% (13/414) cohort of WT-EGFR, KRAS, ALK, } \\
\text { ROS1; } 4.8 \% \text { (11/230) ADC; } 9.5 \% \text { (2/21) PSC }\end{array}$ & Kim et al. (2019) $)^{65}$ \\
\hline China & 46 & PSC & NGS sequencing & $46(45-80)$ & $8.7 \%(4 / 46)$ & Yu et al. (2019) ${ }^{72}$ \\
\hline Netherlands & 1,497 & $\begin{array}{l}\text { Non-SC } \\
\text { NSCLC }\end{array}$ & Amplicon-based NGS & $76.5(53-90)$ & $2.1 \%(32 / 1497)$ & Pruis et al. $(2020)^{78}$ \\
\hline France & 2,369 & NSCLC & Sanger sequencing, NGS & 75 (46-97) & $2.6 \%(62 / 2,369)$ & Champagne et al. $(2020)^{68}$ \\
\hline
\end{tabular}

$A D C=$ adenocarcinoma; $A L K=$ anaplastic lymphoma kinase; $A S C=$ adeno-squamous cell carcinoma; $C G A R N=$ Cancer Genome Atlas Research Network; EGFR = epidermal growth factor receptor; gDNA = genomic DNA; NGS = next-generation sequencing; $N S C L C=$ non-small cell lung carcinoma; $P S C$ = pulmonary sarcomatoid carcinoma; qRT-PCR = quantitative real time RT-PCR; RT-PCR = reverse transcription polymerase chain reaction; $S C=$ squamous cell; $S C C$ = squamous cell carcinoma; TCGA = the cancer genome atlas; WES = whole exome sequencing; $W T=$ wild type.

based panel is ideal for analysing single nucleotide variants and indels (insertions and deletions). NGS analysis also can simultaneously detect other mutations or translocations (such as ALK, ROS1, RET, NTRK1, and $N R G 1$ fusions) in a single assay. ${ }^{83}$ Due to the inherent difficulties in acquiring sufficient RNA material for testing, DNA-based NGS panels are used more frequently to identify METex14 skipping alterations. Recently, the US Food and Drug Administration (FDA) approved FoundationOne ${ }^{\circledR}$ CDx (Foundation Medicine, Cambridge, MA, USA) as a companion diagnostic test for this indication. ${ }^{88}$ Circulating tumor DNA (CtDNA) or RNA from plasma/blood samples (liquid biopsy) can also be used to identify METex14 alterations using NGS technologies. A clinical trial (VISION; ClinicalTrials.gov Identifier: NCTO2864992) aiming to test METex14 skipping alterations in circulating free DNA using plasma liquid biopsy is ongoing. ${ }^{89}$ Some of the commercially available targeted NGS assays that are used to detect these alterations are compared in Table 2.90-101

\section{Therapeutic intervention of NSCLC with METex14 skipping alteration}

NSCLC characterized with METex14 skipping alterations is targetable. ${ }^{57}$ Although many METex14 skipping tumors were found to express programmed death-ligand-1 (PD-L1), the overall response rate to PD-1/PDL1-directed immune checkpoint inhibitors has been found to be low, and median progression-free survival (MPFS) was found to be short in patients with NSCLC. ${ }^{102,103}$ It should be noted that the mutation burden is generally low in such tumors. There are three therapeutic approaches to target tumors harboring METex14 skipping alteration: 
Table 2: Next-generation sequencing assays used in the detection of METex14 skipping in clinical studies

\begin{tabular}{|c|c|c|c|c|c|}
\hline NGS assay & Target & Sample quantity & $\begin{array}{l}\text { Number of } \\
\text { genes covered }\end{array}$ & Detection of mutations & $\begin{array}{l}\text { Turn-over } \\
\text { time }\end{array}$ \\
\hline \multicolumn{6}{|l|}{ Tumor based } \\
\hline Archer ${ }^{\circledast}$ FUSIONPIexTM Lung 91,92 & RNA & FFPE tissue; 2-250 ng DNA & 14 & Not available & Not available \\
\hline FoundationOne ${ }^{\circledast}$ CDx ${ }^{93,94}$ & DNA & 50-1,000 ng DNA & 324 & As low as $2-5 \%$ allele frequency & $<2$ weeks \\
\hline Oncomine focus ${ }^{95}$ & DNA or RNA & $\begin{array}{l}\text { FFPE tissue; } \\
7 \text { mm thick and >5 mm sq }\end{array}$ & 52 & $100 \%$ if mutation is $>5 \%$ allele frequency & 3 days \\
\hline TruSight Oncology 50096 & DNA or RNA & 40 ng DNA or RNA & 523 & $96 \%$ & 4-5 days \\
\hline \multicolumn{6}{|l|}{ Liquid based } \\
\hline Archer ${ }^{\circledast}$ LiquidPlexTM97 & Cell free DNA & 5-10 ng DNA & 28 & If present in >1\% sample & Not available \\
\hline FoundationOne ${ }^{\circledast}$ Liquid 98 & Circulating tumour DNA & $2 \times 8.5 \mathrm{~mL}$ blood samples & 70 & If present in $>0.5 \%$ sample & $<2$ weeks \\
\hline Guardiant360®99,100 & Circulating free DNA & $\begin{array}{l}10 \mathrm{~mL} \text { blood sample for } \\
\text { 5-30 ng DNA }\end{array}$ & 73 & If present in $>0.1 \%$ & 7 days \\
\hline
\end{tabular}

FFPE $=$ formalin-fixed paraffin-embedded; NGS $=$ next-generation sequencing .

- anti-MET and anti-HGF antibodies targeting the extracellular domain of the receptor;

- MET TKIs targeting the intracellular ATP binding pocket of target kinase to inhibit the autophosphorylation of the receptor; and

- antibody-drug conjugates. ${ }^{65,104,105}$

Clinical trials and case-reports have suggested varying degrees of responsiveness to experimental and FDA-approved small molecule TKIs against METex14 skipping NSCLC (Table 3). A multicenter retrospective analysis determined that the treatment with a MET TKI was associated with a significant prolongation in survival with a hazard ratio of 0.11 compared to patients who did not receive any MET inhibitor. ${ }^{106}$ MET TKIs are commonly divided into two types based on their targeting mechanism. Type I MET TKIs — such as crizotinib, capmatinib, tepotinib, and savolitinib-bind to MET in its catalytically active conformation where the aspartic acid-phenylalanineglycine (DFG) motif projects into the ATP-binding site (DFG-in). ${ }^{87,07,108}$ Type ॥ MET TKIs—such as cabozantinib, merestinib, and glesatinib-bind to MET in its inactive DFG-out conformation. ${ }^{109,110}$ Type I MET TKIs are further subdivided into type la (crizotinib) and Ib (capmatinib, tepotinib, and savolitinib) based on the interaction of TKI with G1163, a solvent residue. Various MET TKIs currently being used in clinical trials are listed in Table 4.

\section{Multi-kinase MET inhibitors and their response against METex14 skipping NSCLC}

This group of inhibitors targets multiple TKs and has been used to target MET kinase. Crizotinib, cabozantinib, merestinib, glesatinib, and TPX-0022 are the major target agents in this group.

\section{Crizotinib}

Crizotinib (PF-02341066; Xalkori®, Pfizer, New York, NY, USA) was originally developed as a MET inhibitor, which showed activity against ALK and ROS1 rearrangement, and was approved as an ALK and ROS inhibitor in NSCLC. ${ }^{63,64,111,112}$ Crizotinib was reported to have potent antitumor activity in NSCLC harboring MET amplification and exon 14 skipping alteration.57.87,113 The phase I study PROFILE 1001 (ClinicalTrials.gov Identifier: NCT00585195) was expanded to evaluate the efficacy and safety of crizotinib in 69 patients with NSCLC with METex14 alteration. Among 65 response-evaluable patients, $5 \%$ had a confirmed complete response, $28 \%$ had a confirmed partial response, $45 \%$ had stable disease, and mPFS was 7.4 months. $^{87}$ In 2018, crizotinib received FDA breakthrough therapy designation for the treatment of patients with NSCLC with METex14 alterations based on a promising response rate of up to $44 \%$ in an earlier-phase study. ${ }^{59} \mathrm{~A}$ retrospective study of 22 patients treated with crizotinib reported a similar mPFS of 7.4 months. ${ }^{106}$ However, a phase II study (METROS; ClinicalTrials.gov Identifier: NCT0249961) reported an objective response rate (ORR) of $27 \%$ with an mPFS of 4.4 months in patients with NSCLC $(n=26)$ with MET dysregulation with crizotinib. ${ }^{114}$ Similarly, the AcSé phase II study (by French National Cancer Institute; ClinicalTrials.gov Identifier: NCT02034981) reported insufficient ORR (10.7\%), even after two cycles of crizotinib in 28 patients with NSCLC with METex14 alteration. ${ }^{115}$ Furthermore, neoadjuvant treatment with crizotinib in a locally advanced unresectable METex14 mutated lung adenocarcinoma converted the unresectable tumor into a resectable one. ${ }^{116}$

\section{Cabozantinib}

Cabozantinib (XL-184, BMS-907351; Cabometyx ${ }^{\circledR}$, Exelixis, Alameda, CA, USA) is a multi-kinase inhibitor targeting multiple TKs including MET. Patients with NSCLC with METex14 skipping alteration have shown the partial response to therapy after treatment with cabozantib. ${ }^{107,177}$ In a phase II study of solid tumors (ClinicalTrials.gov Identifier: NCT00940225) ORR was 10\% and mPFS was 4 months. ${ }^{118}$ Importantly, some case studies of patients with NSCLC with METex14 alteration treated with cabozantinib showed intracranial response. ${ }^{117,119}$ Phase II studies in patients with NSCLC with MET deregulation are ongoing (ClinicalTrials.gov Identifier: NCT03911193 [CABinMET study], and ClinicalTrials.gov Identifier: NCT01639508). ${ }^{120}$

\section{Merestinib}

Merestinib (LY2801653) is another multi-kinase ATP-competitive inhibitor of MET. ${ }^{121}$ After the demonstration of an acceptable safety profile and potential antitumor activity in a phase I trial, ${ }^{122}$ a phase II clinical study (ClinicalTrials. gov Identifier: NCT02920996) is ongoing for the treatment of advanced NSCLC harboring METEx14 alterations. A preclinical study demonstrated the antitumor response of merestinib in combination with emibetuzumab in 
Table 3: Agents that target METex14 in development

\begin{tabular}{|c|c|c|c|c|}
\hline Agent & Company & Type of agent & Targets & $\begin{array}{l}\text { Stage of } \\
\text { development }\end{array}$ \\
\hline \multicolumn{5}{|l|}{ Multi-kinase inhibitors } \\
\hline $\begin{array}{l}\text { Crizotinib } \\
\text { (Xalkori®, PF-02341066) }\end{array}$ & Pfizer & la /ATP competitive TKI & MET, ALK, RON, ROS1 & Phase II \\
\hline Cabozantinib (Cabomety $x^{\circledast}, X^{-184)}$ & Exelixis & II/ATP competitive TKI & MET, VEGFR-1/2, RET, KIT, TIE2, FLT1/3/4, AXL & Phase III \\
\hline Merestinib (LY2801653) & Eli Lilly & II/ATP competitive TKI & $\begin{array}{l}\text { MET, AXL, RON, MERTK, ROS1, NTRK1/2/3, TEK, } \\
\text { DDR1/2, FLT3 }\end{array}$ & Phase II \\
\hline Glesatinib (MGCD265) & Mirati Therapeutics & II/ATP competitive TKI & MET, AXL & Phase II \\
\hline TPX-0022 & Turning Point Therapeutics & I/ATP competitive TKI & MET, CSF1R, SRC & Phase I \\
\hline \multicolumn{5}{|l|}{ Selective MET TKI } \\
\hline $\begin{array}{l}\text { Capmatinib } \\
\text { (Tabrecta' }^{T M}, \text { INC280) }^{-}\end{array}$ & Novartis & Ib/ATP competitive TKI & MET & Phase II \\
\hline $\begin{array}{l}\text { Tepotinib (Teometko }{ }^{\circledR}, \text { EMD1214063, } \\
\text { MSC2156119 J) }\end{array}$ & Merck & Ib/ATP competitive TKI & MET & Phase II \\
\hline $\begin{array}{l}\text { Savolitinib } \\
\text { (AZD6094, HMPL-504, volitinib) }\end{array}$ & AstraZeneca & Ib/ATP competitive TKI & MET & Phase II \\
\hline $\begin{array}{l}\text { Bozitinib } \\
\text { (APL-101/PLB-1001, CBT-101) }\end{array}$ & Apollomics & Ib/ATP competitive TKI & MET & Phase I \\
\hline Glumetinib (SCC244) & Shanghai Haihe Pharmaceutical & II/ATP competitive TKI & MET & Phase $1 / / 1$ \\
\hline \multicolumn{5}{|l|}{ Antibodies } \\
\hline Emibetuzumab (LY2875358) & Eli Lilly & IgG4 MoAb & MET & Phase III \\
\hline Sym015 & Symphogen & IgG1 MoAb mixture & MET & Phase I/II \\
\hline REGN5093 & Regeneron Pharmaceuticals & MET bispecific Ab & MET & Phase I/II \\
\hline \multicolumn{5}{|l|}{ Other } \\
\hline Telisotuzumab vedotin (ABBV-399) & AbbVie & Antibody-drug conjugate & MET & Phase II \\
\hline
\end{tabular}

$A b=$ antibody; $A L K=$ anaplastic lymphoma kinase; $A T P=$ adenosine triphosphate; $C S F 1 R=$ colony stimulating factor 1 receptor; $D D R 1 / 2=$ discoidin domain receptor tyrosine kinase 1/2; FLT3 = fms-like tyrosine kinase 3; Ig = immunoglobulin; MERTK = MER receptor tyrosine kinase; MoAb = monoclonal antibody; NTRK= neurotrophic-tropomyosin receptor kinase; $R O N=$ receptor originated from Nantes; $R O S 1=c$-ros oncogene 1; TIE2 = tyrosine-protein kinase receptor; TKI = tyrosine kinase inhibitor; VEGFR = vascular endothelial growth factor receptor.

a mouse model with METex14 skipping alteration. ${ }^{121}$ Recently, merestinib demonstrated antitumor activity in a patient with lung cancer harboring METex14 skipping and acquired resistance against capmatinib and crizotinib. ${ }^{123}$

\section{Glesatinib}

Glesatinib (MGCD265) is also a multi-kinase inhibitor of MET, AXL, VEGFR1/2/3, RON, and TIE2, which demonstrated antitumor activity in preclinical and clinical studies with METex14 alteration. ${ }^{109,124}$ A phase ॥ study (ClinicalTrials.gov Identifier: NCT02544633) showed the antitumor activity of glesatinib in patients who had METex14 skipping alteration and acquired resistance against crizotinib. ${ }^{109,123,125}$

\section{TPX-0022}

TPX-0022 is a novel multi-kinase inhibitor of MET, CSF1R, and SRC, which demonstrated antitumor activity in preclinical xenograft models. ${ }^{126} \mathrm{~A}$ recent phase I clinical study reported that TPX-0022 was well tolerated, and responses were observed in patients with advanced solid tumors harboring genetic MET alterations (ClinicalTrials.gov Identifier: NCT03993873). ${ }^{127}$

\section{Selective kinase MET inhibitor on METex14 skipping NSCLC}

This group of inhibitors specifically target the MET receptor by binding to the ATP binding pocket of the MET kinase. Application of such selective
MET inhibitors has produced a promising response in patients with METex14 skipping alteration. Capmatinib, tepotinib, savolitinib, and APL-101 are among the promising agents in this group.

\section{Capmatinib}

Capmatinib (INC280; Trabecta' ${ }^{\text {TM }}$, Novartis, Basel, Switzerland) is a highlyselective, ATP-competitive MET inhibitor and the first and only MET inhibitor approved by the FDA to target metastatic NSCLC with METex14 skipping alteration as determined by an FDA-approved test. ${ }^{128-130}$ The approval is based on the results from the pivotal GEOMETRY phase II study (ClinicalTrials.gov Identifier: NCT02414139). The primary efficacy outcome based on ORR was $68 \%$ and $41 \%$ among 28 treatment-naive and 69 previously treated patients, respectively, based on the blinded independent review committee assessment. The median DOR was 12.6 months $(n=19)$ for treatment-naive and 9.7 months $(n=28)$ for pre-treated patients. ${ }^{131,132}$ Importantly, capmatinib also exhibited antitumor activity in patients with brain metastases in previously treated NSCLC harboring METex14 alterations. ${ }^{108,133}$

\section{Tepotinib}

Tepotinib (END 1214063; Tepmetko ${ }^{\circledR}$, Merck KGaA, Darmstadt, Germany) is an ATP-competitive and highly-selective oral MET inhibitor, which showed MET inhibitory activity in in vitro and in vivo models. It supressed MET activation by both ligand-dependent and independent mechanisms. ${ }^{134}$ 
Table 4: Clinical studies of various MET TKIs in NSCLC with METex14 skipping alteration and observation (final/interim reports)

\begin{tabular}{|c|c|c|c|c|c|}
\hline $\begin{array}{l}\text { Clinicaltrials.gov Identifier/ } \\
\text { phase/location }\end{array}$ & Recruited patients & $\begin{array}{l}\text { Population and prior } \\
\text { treatment }\end{array}$ & Drug/dose & $\begin{array}{l}\text { Responses } \\
\text { evaluated patients }\end{array}$ & $\begin{array}{l}\text { Observations } \\
\text { (final/interim reports) }\end{array}$ \\
\hline $\begin{array}{l}\text { NCT00585195 } \\
\text { (PROFILE-1001)/phase I/US }\end{array}$ & NSCLC with METex14 skipping & 69 (62\% pre-treated) & $\begin{array}{l}\text { cizotinib, } 250 \mathrm{mg} \\
\text { BID }\end{array}$ & 65 & $\begin{array}{l}\text { ORR: } 32 \% \text { (95\% Cl: } 21-45) ; \\
\text { DOR: } 9.1 \text { months (95\% Cl: 6.4-12.7); } \\
\text { mPFS: } 7.3 \text { months (95\% Cl: 5.4-9.1) })^{87}\end{array}$ \\
\hline $\begin{array}{l}\text { NCT02499614 } \\
\text { (METROS)/phase II/Italy }\end{array}$ & $\begin{array}{l}\text { NSCLC with METex14 skipping } \\
\text { or MET amplification }\end{array}$ & 26 (100\% pre-treated) & $\begin{array}{l}\text { cizotinib, } 250 \mathrm{mg} \\
\text { BID }\end{array}$ & 26 & $\begin{array}{l}\text { ORR: } 27 \% \text { (95\% Cl: } 11-47) \\
\text { mPFS: } 4.4 \text { months (95\% Cl: } 3.0-5.8) \\
\text { OS: } 5.4 \text { months }(95 \% \mathrm{Cl}: 4.2-6.5)^{114}\end{array}$ \\
\hline $\begin{array}{l}\text { NCT02034981 } \\
\text { (AcSé)/phase II/France }\end{array}$ & $\begin{array}{l}\text { NSCLC with METex14 skipping } \\
\text { or MET amplification }\end{array}$ & 28 (96\% pre-treated) & $\begin{array}{l}\text { cizotinib, } 250 \mathrm{mg} \\
\text { BID }\end{array}$ & 25 & $\begin{array}{l}\text { ORR: } 10.7 \% \text { (95\% Cl: 2.3-28.2); } \\
\text { mPFS: } 2.4 \text { mo (95\% Cl: 1.6-5.9); } \\
\text { median OS: } 8.1 \text { mo (95\% Cl: } 4.1-12.7)^{115}\end{array}$ \\
\hline $\begin{array}{l}\text { NCT02664935 } \\
\text { (National Lung Matrix)-Arm } \\
\text { D3/phase II/UK }\end{array}$ & $\begin{array}{l}\text { NSCLC including METex14 } \\
\text { skipping }\end{array}$ & 12 (100\% pre-treated) & $\begin{array}{l}\text { Multi-drug } \\
\text { (including } \\
\text { crizotinib, } 250 \mathrm{mg} \\
\text { BID) }\end{array}$ & 8 & $\begin{array}{l}\text { ORR: 65\% (95\% Cl: 39-86); } \\
\text { DCB: 68\% (95\% Cl: 39-89) }\end{array}$ \\
\hline $\begin{array}{l}\text { NCT01324479/ } \\
\text { phase I/global }\end{array}$ & NSCLC with MET dysregulated & 55 (100\% pre-treated) & $\begin{array}{l}\text { capmatinib, } 400 \text { or } \\
600 \mathrm{mg} \mathrm{BID}\end{array}$ & 55 & $\begin{array}{l}\text { ORR: } 20 \% \text { ( } 95 \% \text { Cl: } 10.4-33) \text {; } \\
\text { Tumour responses in all } 4 \text { patients } \\
\text { with METex14153,154 }\end{array}$ \\
\hline $\begin{array}{l}\text { NCT02414139 } \\
\text { (GEOMETRY mono 1)/phase } \\
\text { II/global }\end{array}$ & $\begin{array}{l}\text { NSCLC with CMET mutation or } \\
\text { gene copy number or CMET } \\
\text { dysregulation }\end{array}$ & $\begin{array}{l}97 \text { ( } 28 \text { prior } \\
\text { treatment-naive and } \\
69 \text { pre-treated) }\end{array}$ & $\begin{array}{l}\text { capmatinib, } \\
400 \text { mg BID }\end{array}$ & $\begin{array}{l}28 \text { treatment-naive } \\
\text { and } 69 \text { pre-treated }\end{array}$ & $\begin{array}{l}\text { Treatment-naive: } \\
\text { ORR: 68\% (95\% Cl: 48-84); } \\
\text { median DOR: } 12.6 \text { months } \\
\text { (95\% Cl: } 5.5-25.3) \\
\text { Pretreated patients: } \\
\text { ORR: 41\% (95\% Cl: } 29-53) \text {; } \\
\text { mPFS: } 9.7 \text { months } \\
\text { (95\% Cl: 5.5-13.0) }{ }^{132,155,156}\end{array}$ \\
\hline $\begin{array}{l}\text { NCT02864992 } \\
\text { (VISION)/phase II/global }\end{array}$ & $\begin{array}{l}\text { NSCLC with METex14 skipping } \\
\text { or MET amplification }\end{array}$ & $\begin{array}{l}99 \text { ( } 43 \text { prior } \\
\text { treatment-naive and } \\
56 \text { pre-treated) }\end{array}$ & $\begin{array}{l}\text { tepotinib, } 500 \\
\text { mg QD }\end{array}$ & $\begin{array}{l}99 \text { combined } \\
\text { biopsy; } \\
66 \text { liquid biopsy; } \\
60 \text { tissue biopsy }\end{array}$ & 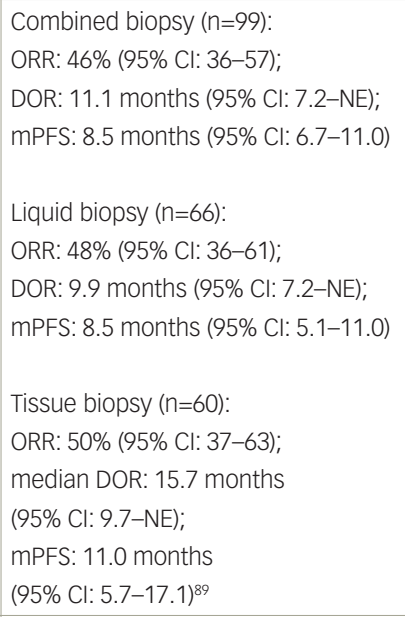 \\
\hline NCT02897479/phase II/China & $\begin{array}{l}\text { NSCLC } \\
\text { (PSC and other NSCLC with } \\
\text { METex14 skipping) }\end{array}$ & $\begin{array}{l}70 \text { (prior MET treatment- } \\
\text { naive) }\end{array}$ & $\begin{array}{l}\text { savolitinib, } 600 \text { mg } \\
\text { QD or } 400 \text { mg QD }\end{array}$ & 61 & $\begin{array}{l}\text { ORR: } 47.5 \% \text { (95\% Cl: } 34.6-60.7) ; \\
\text { DCR: } 93.4 \% \text { (95\% Cl: 84.1-98.2); } \\
\text { mPFS: } 6.8 \text { months } \\
(95 \% \text { Cl: } 4.2-13.8)^{139}\end{array}$ \\
\hline
\end{tabular}

$B I D=$ twice daily; $C l=$ confidence interval; $D C B=$ durable clinical benefit; $D C R=$ disease control rate; $D O R=$ duration of response; $m P F S=$ median progression-free survival; $N E=$ not evaluable; NSCLC = non-small cell lung cancer; ORR = objective response rate; OS = overall survival; $P S C=$ pulmonary sarcomatoid carcinoma; $Q D=$ once daily; $T K I=$ tyrosine kinase inhibitor.

In March 2020, regulatory authority in Japan approved tepotinib for the treatment of NSCLC with METex14 skipping alteration. ${ }^{135}$ The approval was based on data from 99 patients with NSCLC with METex14 skipping alteration who had been followed up for 9 months in the ongoing singlearm phase II VISION study (ClinicalTrials.gov Identifier: NCT02864992). The primary endpoint ORR of the study, as assessed by an independent review committee, was $46 \%$ with median DOR of 11.1 months for patients identified by combined biopsy (liquid/tissue biopsy). The response rate was $48 \%$ for patients in the liquid biopsy group ( $n=66$ ), and was $50 \%$ for those in the tissue biopsy group $(n=60) .{ }^{89}$ The FDA granted tepotinib a breakthrough therapy designation for the treatment of NSCLC harboring METex14 skipping alterations in September 2019. Recently, a case of antitumor activity of tepotinib in a patient with NSCLC with brain metastasis harboring a MET gene rearrangement was reported. ${ }^{136}$ 


\section{Savolitinib}

Savolitinib (volitinib, AZD6094, AstraZeneca, Cambridge, UK) is also a highly selective MET inhibitor. ${ }^{137,138}$ Interim data from a phase II study (ClinicalTrials.gov Identifier: NCT02897479) reported encouraging antitumor activity and an acceptable safety profile of savolitinib in patients with METex14 skipping NSCLC, including pulmonary sarcomatoid and other histologies. The ORR from preliminary data $(n=61)$ was $47.5 \%$ and mPFS was 6.8 months..$^{139}$

\section{APL-101}

APL-101 (bozitinib, CBT-101, PLB-1001), another highly selective MET TKI, has demonstrated robust anticancer activity in various human xenograft tumor models with MET dysregulation and bears the potential to cross the blood-brain barrier in glioblastoma. ${ }^{140,141}$ Currently, SPARTA, a phase I/ II study (ClinicalTrials.gov Identifier: NCT03175224) is evaluating antitumor activity of APL-101 in patients with NSCLC with METex14 skipping and solid tumors with MET aberrations.

\section{Glumetinib}

Glumetinib (SCC244) is a highly-selective, ATP-competitive MET inhibitor. The antitumor activity of this agent was demonstrated as equivalent to capmatinib in a preclinical study. ${ }^{142} \mathrm{Currently,} \mathrm{phase} \mathrm{I} \mathrm{studies} \mathrm{(ClinicalTrials.gov}$ Identifier: NCT03466268) in patients with NSCLC with MET alterations, and another study (ClinicalTrials.gov Identifier: NCT03457532) in patients with solid tumors harboring MET alterations are ongoing for the evaluation of the safety and antitumor activity of glumetinib. A global phase I/II study (ClinicalTrials.gov Identifier: NCT04270591) for patients with NSCLC with MET alterations is also ongoing.

\section{The effect of MET antibodies on METex14 skipping NSCLC Emibetuzumab}

Emibetuzumab (LY2875358) is a humanized bivalent anti-MET antibody that has high neutralization and internalization activities. It showed potent antitumor activity to inhibit HGF-dependent and HGF-independent tumor growth in mouse xenograft models and in MET-positive (including NSCLC) patients. ${ }^{13,1,44} \mathrm{~A}$ preclinical study revealed more antitumor activity of emibetuzumab combined with merestinib on gastric cancer with METex14 muation. ${ }^{121}$

\section{Onartuzumab}

Onartuzumab is another antibody drug that has shown antitumor activity in preliminary studies. However, it failed to improve the clinical outcomes of MET-positive patients compared with placebo in phase III studies. ${ }^{145}$

\section{SYM015}

SYM015 is a combination of two humanized antibodies directed at the elimination of the MET receptors. ${ }^{146}$ In a phase I/II study (ClinicalTrials.gov Identifier: NCT02648724), the safety and efficacy of Sym015 in patients with advanced NSCLC with MET amplification and exon 14 deletion were observed. Of 20 patients with NSCLC, the ORR was $25 \%$ and the disease control rate was $80 \%$, with median PFS of 5.5 months. ${ }^{177}$

\section{REGN5093}

REGN5093 is a MET biparatopic antibody that blocks HGF binding and causes rapid internalization and degradation of MET. ${ }^{148} \mathrm{~A}$ phase I/II study (ClinicalTrials.gov Identifier: NCT04077099) demonstrated the safety and tolerability of REGN5093 in patients with NSCLC with MET alterations. ${ }^{199}$ This study is ongoing and is open for enrollment of patients.

\section{The impact of antibody-drug conjugates on METex14 alteration Telisotuzumab vedotin}

Telisotuzumab vedotin (ABBV-399) is a conjugate of a MET-targeted antibody and monomethyl auristatin E. This antibody-drug conjugate has demonstrated antitumor activity in patients NSCLC with MET dysregulation in a preliminary analysis from a phase I study. ${ }^{150,151}$

\section{Resistance of METex14 skipping alterations to MET TKIs}

Reports suggest that patients with NSCLC with METex14 skipping alterations are sensitive to MET TKI treatment.87,107,111 However, emergence of primary or acquired resistance may challenge the efficacy of MET TKIbased monotherapy. ${ }^{11,123,157}$ Clinically, the analysis of pre- and post-MET TKI treatment data from 20 patients showed 35\% on-target and $45 \%$ off-target resistance acquired after the treatment. ${ }^{123}$ Even though MET is exclusively a driver gene in many cancers, in some cases, METex14 skipping alterations may exist with alterations in other driver genes, such as amplifications of MDM2 (25-35\%), CDK4 (3-21\%), and EGFR (6-29\%), leading to MET TKI resistance. Furthermore, mutations or amplification of KRAS (3-7\%) and PIK3CA (3-10\%), and loss of PTEN expression (23\%) may exist with METex14 skipping alterations contributing to resistance.

The pre-existence of MET Y1230C on-target mutation in addition to METex14 skipping alteration has accounted for the primary resistance to crizotinib. 158,159 MET-D1228N-acquired mutation was found to be responsible for the resistance to crizotinib in a patient with METex14 skipping alteration, who did not have any additional mutation in MET or other driver genes before the treatment started. ${ }^{11}$ A comprehensive analysis of secondary mutations using a Ba/F3 model resistance to eight TKIs reported that D1228 and Y1230 are common sites for resistance mutations for type I TKIs, whereas $L 1195$ and F1200 are the mutations leading to resistance to type II TKIs. D1228A/Y accounts for resistance to both type I and II MET TKIs. ${ }^{160}$

In addition, tumor cells may activate other signaling pathways to counterbalance the MET TKI suppressed signaling. In such cases, alterations leading to overexpression of key proteins drive the activation of alternative receptors, which leads to the sustained activation of major signaling pathways (bypass signaling) and contributes to the therapeutic resistance, regardless of effective MET inhibition by MET TKI drugs. On the other hand, MET dysregulation, mostly due to METex14 skipping alteration, has also been observed in NSCLC tumors because of off-target acquired resistance to EGFR TKIs. ${ }^{161}$

Identification of the resistance mechanism to MET TKIs is crucial for the effective treatment of NSCLC. For example, tumors developing acquired resistance against glesatinib (type II) through the amplification of the mutated METex14 allele showed partial response after switching to crizotinib (type la). ${ }^{160}$ Merestinib (type II) was reported to function better against D1228N-mediated acquired resistance, which developed after the application of capmatinib (type Ib). ${ }^{109}$ Similarly, glesatinib (type II) revealed better antitumor activity in $\mathrm{Y} 1230 \mathrm{H} / \mathrm{S}$ mutation, which developed after crizotinib (type la) treatment. ${ }^{123}$ Preclinical 
and clinical data have demonstrated that tumors harboring METex14 skipping alterations along with other mutations, RAS-MAPK or PI3K/AKT pathway mutations, show reduced response to MET TKIS. ${ }^{162-164}$ Overall, the resistance mechanisms against different types of MET inhibitor can be different. ${ }^{109}$ Therapy combining relevant inhibitors can be helpful for the treatment of NSCLC with METex14 skipping alteration along with other driver mutations. ${ }^{164,165}$ Extensive studies are needed to unravel the full spectrum of resistance mechanisms against the inhibitor drugs for optimising therapeutic intervention.

\section{Conclusion and outlook}

MET abnormalities due to METEX14 skipping alteration can drive cancer by upregulating receptor activity. It has become a promising target for kinase inhibitor-based targeted therapy in NSCLC, and several recent clinical trials have demonstrated the strong therapeutic effect of such inhibitors. However, it is not yet available to many potential patients who could benefit from such therapy. Firstly, current guidelines do not necessitate the analysis of METex14 skipping alterations for a standard treatment plan, missing the identification of such mutations in many patients and consequently precluding a possible target group from receiving MET inhibitors. Secondly, many early-stage patients may not be subjected to molecular profiling due to the complexity in accessing the tissue biopsy sample. In such cases, application of liquid biopsy and ctDNA genotyping can ease sample availability, which can widen the scope of diagnosis, thereby enabling more patients to get a proper diagnosis and therapy. In addition, a detailed understanding of primary and acquired resistance mechanisms can aid in decision making for the appropriate therapeutic intervention. More clinical trials focusing on the combination of MET inhibitors with inhibitors of other signaling pathways can help to identify an appropriate drug combination in MET inhibitor-resistant cancers. $]$
1. Cancer Genome Atlas Research Network. Comprehensive molecular profiling of lung adenocarcinoma. Nature. 2014;511:543-50.

2. Pao W, Girard N. New driver mutations in non-small-cell lung cancer. Lancet Oncol. 2011;12:175-80.

3. Kris MG, Johnson BE, Berry LD, et al. Using multiplexed assays of oncogenic drivers in lung cancers to select targeted drugs. JAMA. 2014;311:1998-2006.

4. Linardou H, Dahabreh $\Perp$, Bafaloukos D, et al. Somatic EGFR mutations and efficacy of tyrosine kinase inhibitors in NSCLC. Nat Rev Clin Oncol. 2009;6:352-66.

5. Awad MM, Shaw AT. ALK inhibitors in non-small cell lung cancer crizotinib and beyond. Clin Adv Hematol Oncol. 2014;12:429-39.

6. Trusolino L, Bertotti A, Comoglio PM. MET signalling: principles and functions in development, organ regeneration and cancer. Nat Rev Mol Cell Biol. 2010;11:834-48.

7. Koch JP, Aebersold DM, Zimmer Y, Medová M. MET targeting: time for a rematch. Oncogene. 2020:39:2845-62.

8. Birchmeier C, Birchmeier W, Gherardi E, Vande Woude GF Met, metastasis, motility and more. Nat Rev Mol Cell Biol. 2003;4:915-25

9. Boccaccio C, Comoglio PM. Invasive growth: a MET-driven genetic programme for cancer and stem cells. Nat Rev Cancer. 2006:6:637-45

10. Engelman JA, Zejnullahu K, Mitsudomi T, et al. Amplification leads to gefitinib resistance in lung cancer by activating ERBB3 signaling. Science. 2007;316:1039-43.

11. Heist RS, Sequist LV, Borger D, et al. Acquired resistance to crizotinib in NSCLC with MET Exon 14 skipping. J Thorac Oncol. 2016;11:1242-5.

12. Cappuzzo F, Jänne PA, Skokan M, et al. MET increased gene copy number and primary resistance to gefitinib therapy in non-smallcell lung cancer patients. Ann Oncol. 2009:20:298-304.

13. Giordano S, Maffe A, Williams T, et al. Different point mutations in the met oncogene elicit distinct biological properties. FASEB $\rfloor$ 2000;14:399-406.

14. Organ SL, Tsao M-S. An overview of the C-MET signalling pathway. Ther Adv Med Oncol. 2011;(Suppl.3):S7-S19.

15. Kong-Beltran $\mathrm{M}$, Seshagiri $\mathrm{S}$, Zha J, et al. Somatic mutations lead to an oncogenic deletion of Met in lung cancer. Cancer Res. 2006;66:283-9.

16. Inokuchi M, Otsuki S, Fujimori Y, et al. Clinical significance of MET in gastric cancer. World J Gastrointest Oncol. 2015;7:317-27.

17. Kim JH, Kim HS, Kim BJ. Prognostic value of MET copy number gain in non-small-cell lung cancer: an updated meta-analysis. J Cancer. 2018;9:1836-45.

18. Tong JH, Yeung SF, Chan AWH, et al. Amplification and Exon 14 splice site mutation define unique molecular subgroups of nonsmall cell lung carcinoma with poor prognosis. Clin Cancer Res. 2016;22:3048-56.

19. Cooper CS, Park M, Blair DG, et al. Molecular cloning of a new transforming gene from a chemically transformed human cell line. Nature. 1984;311:29-33.

20. Park M, Dean M, Cooper CS, et al. Mechanism of met oncogene activation. Cell. 1986;45:895-904.

21. Park M, Dean M, Kaul K, et al. Sequence of MET protooncogene CDNA has features characteristic of the tyrosine kinase family of growth-factor receptors. Proc Natl Acad Sci U S A. 1987;84:6379-83.

22. Gherardi $\mathrm{E}$, Youles ME, Miguel RN, et al. Functional map and domain structure of MET, the product of the c-met protooncogene and receptor for hepatocyte growth factor/ scatter factor. Proc Natl Acad Sci U S A. 2003;100:12039-44.

23. Wickramasinghe $\mathrm{D}$, Kong-Beltran $\mathrm{M}$. met activation and receptor dimerization in cancer: a role for the Sema domain. Cell Cycle. 2005;4:683-5.

24. Kong-Beltran M, Stamos J, Wickramasinghe D. The Sema domain of Met is necessary for receptor dimerization and activation. cancer Cell. 2004;6:75-84.
25. Kozlov G, Perreault A, Schrag JD, et al. Insights into function of PSI domains from structure of the Met receptor PSI domain. Biochem Biophys Res Comm. 2004;321:234-40.

26. Nakamura T, Nishizawa T, Hagiya M, et al. Molecular cloning and expression of human hepatocyte growth factor. Nature. 1989;342:440-3.

27. Weidner KM, Arakaki N, Hartmann G, et al. Evidence for the identity of human scatter factor and human hepatocyte growth factor. Proc Natl Acad Sci U S A. 1991;88:7001-5.

28. Bottaro D, Rubin J, Faletto D, et al. Identification of the hepatocyte growth factor receptor as the c-met proto-oncogene product. Science. 1991;251:802-4

29. Ponzetto C, Bardelli A, Zhen Z, et al. A multifunctional docking site mediates signalling and transformation by the hepatocyte growt factor/scatter factor receptor family. Cell. 1994;77:261-71.

30. Fixman ED, Fournier TM, Kamikura DM, et al. Pathways downstream of Shc and Grb2 are required for cell transformation by the Tpr-Met oncoprotein. J Biol Chem. 1996;271:13116-22.

31. Weidner KM, Di Cesare S, Sachs M, et al. Interaction between Gab1 and the c-Met receptor tyrosine kinase is responsible for epithelial morphogenesis. Nature. 1996;384:173-6.

32. Maina F, Casagranda F, Audero E, et al. Uncoupling of Grb2 from the Met receptor in vivo reveals complex roles in muscle development. Cell. 1996:87:531-42.

33. Furge KA, Kiewlich $D$, Le $P$, et al. Suppression of Rasmediated tumorigenicity and metastasis through inhibition of the Met receptor tyrosine kinase. Proc Natl Acad Sci U S A. 2001;98:10722-7.

34. Zhang Y-W, Wang L-M, Jove R, Vande Woude GF. Requirement of Stat3 signalling for HGF/SF-Met mediated tumorigenesis. Oncogene. 2002;21:217-26.

35. Graziani A, Gramaglia D, dalla Zonca P, Comoglio PM. Hepatocyte growth factor/scatter factor stimulates the Ras-guanine nucleotide exchanger I Biol Chem 1993.268:9165-8.

36. Fan $\mathrm{S}$, Gao M, Meng $\mathrm{Q}$, et al. Role of NF-kB signalling in hepatocyte growth factor/scatter factor-mediated cell protection. oncogene. 2005;24:1749-66.

37. Bladt F, Riethmacher D, Isenmann S, et al. Essential role for the c-met receptor in the migration of myogenic precursor cells into the limb bud. Nature. 1995;376:768-71.

38. Borowiak M, Garratt AN, Wüstefeld T, et al. Met provides essential signals for liver regeneration. Proc Natl Acad Sci U S A 2004;101:10608-13.

39. Huh C-G, Factor VM, Sánchez A, et al. Hepatocyte growth factor signalling pathway is required for efficient liver regeneration and repair. Proc Natl Acad Sci U S A. 2004;101:4477-82

40. Peschard P, Fournier TM, Lamorte $L$, et al. Mutation of the $\mathrm{c}-\mathrm{Cb}$ TKB domain binding site on the Met receptor tyrosine kinase converts it into a transforming protein. Mol Cell. 2001;8:995-1004.

41. Abella JV, Peschard P, Naujokas MA, et al. Met/Hepatocyte growth factor receptor ubiquitination suppresses transformation and is required for Hrs phosphorylation. Mol Cell Biol. 2005;25:9632-45.

42. Joffre $C$, Barrow R, Ménard $L$, et al. A direct role for Met endocytosis in tumorigenesis. Nat Cell Biol. 2011;13:827-37.

43. Hammond DE, Urbé S, Vande Woude GF, Clague MJ. Downregulation of MET, the receptor for hepatocyte growth factor. Oncogene. 2001;20:2761-70.

44. Hashigasako A, Machide M, Nakamura T, et al. Bi-directional regulation of Ser-985 phosphorylation of c-Met via protein kinase $\mathrm{C}$ and protein phosphatase $2 \mathrm{~A}$ involves C-Met activation and cellular responsiveness to hepatocyte growth factor. J Biol Chem. 2004;279:26445-52

45. Foveau B, Ancot F, Leroy C, et al. Down-regulation of the me receptor tyrosine kinase by presenilin-dependent regulated intramembrane proteolysis. Mol Biol Cell. 2009:20:2495-507.

46. Schelter F, Kobuch J, Moss ML, et al. A disintegrin and metalloproteinase-10 (ADAM-10) mediates DN30 antibodyinduced shedding of the met surface receptor. J Biol Chem.

\section{0:285.26335-40.}

47. Sacco JJ, Clague MJ. Dysregulation of the Met pathway in non-small cell lung cancer: implications for drug targeting and resistance. Trans/ Lung Cancer Res. 2015;4:242-52.

48. Zhang Y, Xia M, Jin K, et al. Function of the c-Met receptor tyrosine kinase in carcinogenesis and associated therapeutic opportunities. Mol Cancer. 2018;17:45.

49. Liang $\mathrm{H}$, Wang M. MET Oncogene in non-small cell lung cancer: mechanism of MET dysregulation and agents targeting the HGF/C Met axis. Onco Targets Ther. 2020;13:2491-510.

50. Salgia R. MET in lung cancer: biomarker selection based on scientific rationale. Mol Cancer Ther. 2017;16:555-65.

51. Ma PC, Tretiakova MS, MacKinnon AC, et al. Expression and mutational analysis of MET in human solid cancers. Genes Chromosomes Cancer. 2008;47:1025-37.

52. Tsuta K, KozU Y, Mimae T, et al. c-MET/Phospho-MET protein expression and MET gene copy number in non-small cell lung carcinomas. I Thorac Oncol. 2012:7:331-9.

53. Park S, Choi YL, Sung CO, et al. High MET copy number and MET overexpression: poor outcome in non-small cell lung cancer patients. Histol Histopathol. 2012;27:197-207.

54. Okuda K, Sasaki H, Yukiue H, et al. Met gene copy number predicts the prognosis for completely resected non-small cell lung cancer. Cancer Sci. 2008;99:2280-5.

55. Ma PC, Jagadeeswaran R, Jagadeesh $\mathrm{S}$, et al. Functional expression and mutations of C-Met and its therapeutic inhibition with SU11274 and small interfering RNA in non-small cell lung cancer. Cancer Res. 2005;65:1479-88.

56. Drilon A. MET EXon 14 alterations in lung cancer: exon skipping extends half-life. Clin Cancer Res. 2016;22:2832-4

57. Frampton GM, Ali SM, Rosenzweig M, et al. Activation of MET via diverse exon 14 splicing alterations occurs in multiple tumo types and confers clinical sensitivity to MET inhibitors. Cancer Discov. 2015:5:850-9.

58. Weidner KM, Sachs M, Riethmacher D, Birchmeier W. Mutation of juxtamembrane tyrosine residue 1001 suppresses loss-offunction mutations of the met receptor in epithelial cells. Proc Natl Acad Sci U S A. 1995;92:2597-601.

59. Drilon A, Cappuzzo F, Ou S-HI, Camidge DR. Targeting MET in lung cancer. will expectations finally be MET? J Thorac Onco. 2017;12:15-26.

60. Cortot AB, Kherrouche Z, Descarpentries C, et al. Exon 14 deleted MET receptor as a new biomarker and target in cancers J Natl Cancer Inst. 2017;109. doi:10.1093/ jnci/djw262.

61. Van Der Steen N, Giovannetti E, Pauwels P, et al. CMET exon 14 skipping: From the structure to the clinic. J Thorac Oncol. 2016;11:1423-32

62. Pilotto S, Gkountakos A, Carbognin L, et al. MET exon 14 juxtamembrane splicing mutations: clinical and therapeutical perspectives for cancer therapy. Ann Trans/ Med. 2017:5:2.

63. Awad MM, Oxnard GR, Jackman DM, et al. MET Exon 14 mutations in non-small-cell lung cancer are associated with advanced age and stage-dependent MET genomic amplification and c-Met overexpression. J Clin Oncol. 2016;34:721-30.

64. Lee GD, Lee SE, Oh D-Y, et al. MET exon 14 skipping mutations in lung adenocarcinoma: clinicopathologic implications and prognostic values. J Thorac Oncol. 2017;12:1233-46.

65. Kim EK, Kim KA, Lee $\mathrm{CY}$, et al. Molecular diagnostic assays and clinicopathologic implications of MET Exon 14 skipping mutation in non-small-cell lung cancer. Clin Lung Cancer. 2019;20:e123-32.

66. Qiu T, Li W, Zhang T, et al. Distinct MET protein localization associated with MET exon 14 mutation types in patients with non-small-cell lung cancer. Clin Lung Cancer. 2018;19:e391-8.

67. Suzawa K, Offin M, Lu D, et al. Activation of KRAS mediates resistance to targeted therapy in MET exon 14-mutant non-small cell lung cancer. Clin Cancer Res. 2019:25:1248-60.

68. Champagnac A, Bringuier P-P, Barritault M, et al. Frequency of MET exon 14 skipping mutations in non-small cell lung cancer 
according to technical approach in routine diagnosis: results from a real-life cohort of 2,369 patients. J Thorac Dis. 2020;12:2172-8.

69. Liu X, Jia Y, Stoopler MB, et al. Next-generation sequencing of pulmonary sarcomatoid carcinoma reveals high frequency of actionable MET gene mutations. J Clin Oncol. 2015:34:794-802.

70. Kwon D, Koh J, Kim S, et al. MET exon 14 skipping mutation in triple-negative pulmonary adenocarcinomas and pleomorphic carcinomas: An analysis of intratumoral MET status heterogeneity and clinicopathological characteristics. Lung Cancer. 2017:106:131-7.

71. Saffroy R, Fallet V, Girard N, et al. MET exon 14 mutations as targets in routine molecular analysis of primary sarcomatoid carcinoma of the lung. Oncotarget. 2017;8:42428-37.

72. Yu Y, Zhang Q, Zhang J, Lu S. Prevalence of MET exon 14 skipping mutation in pulmonary sarcomatoid carcinoma patients without common targetable mutations: A single-institute study. J Cancer Res Ther. 2019;15:909-13

73. Zheng $\mathrm{D}$, Wang $\mathrm{R}$, Ye T, et al. MET exon 14 skipping defines a unique molecular class of non-small cell lung cancer. Oncotarget. 2016;7:41691-702.

74. Schrock AB, Frampton GM, Suh J, et al. Characterization of 298 patients with lung cancer harboring MET Exon 14 skipping alterations. I Thorac Oncol. 2016:11:1493-502.

75. Park S, Koh 」, Kim D-W, et al. MET amplification, protein expression, and mutations in pulmonary adenocarcinoma. Lung Cancer. 2015;90:381-7.

76. Yeung SF, Tong JHM, Law PPW, et al. Profiling of oncogenic driver events in lung adenocarcinoma revealed MET mutation as independent prognostic factor. J Thorac Oncol. 2015;10:1292-300.

77. Gow C-H, Hsieh M-S, Wu S-G, Shih J-Y. A comprehensive analysis of clinical outcomes in lung cancer patients harbouring a MET exon 14 skipping mutation compared to other driver mutations in an East Asian population. Lung Cancer. 2017;103:82-9.

78. Pruis MA, Geurts-Giele WRR, von der TJH, et al. Highly accurate DNA-based detection and treatment results of MET exon 14 skipping mutations in lung cancer. Lung Cancer. 2020;140:46-54.

79. Heist RS, Shim HS, Gingipally S, et al. MET exon 14 skipping in nonsmall cell lung cancer. Oncologist. 2016;21:481-6.

80. Liu S-Y, Gou L-Y, Li A-N, et al. The unique characteristics of MET exon 14 mutation in chinese patients with NSCLC. J Thorac Oncol. 2016;11:1503-10.

81. Jordan EJ, Kim HR, Arcila ME, et al. Prospective comprehensive molecular characterization of lung adenocarcinomas for efficien patient matching to approved and emerging therapies. Cancer Discov. 2017;7:596-609.

82. Li Y, Gao L, Ma D, et al. Identification of MET exon14 skipping by targeted DNA- and RNA-based next-generation sequencing in pulmonary sarcomatoid carcinomas. Lung Canc. 2018;122:113-9.

83. Davies KD, Lomboy A, Lawrence CA, et al. DNA-based versus RNA-based detection of MET exon 14 skipping events in lung cancer. J Thorac Oncol. 2019;14:737-41.

84. Planchard D, Popat S, Kerr K, et al. Metastatic non-small cell lung cancer: ESMO Clinical Practice Guidelines for diagnosis, treatment and follow-up. Ann Oncol. 2018:29:iv192-237.

85. Planchard D, Popat S, Kerr K, et al. Metastatic non-small cell lung cancer: ESMO Clinical Practice Guidelines for diagnosis, treatment and follow-up. 2020. Available at: www.esmo.org/content/ download/347819/6934778/1/ESMO-CPG-mNSCLC-15SEPT2020 pdf (accessed January 14, 2021).

86. Ma PC, Kijima T, Maulik G, et al. C-MET mutational analysis in small cell lung cancer: novel juxtamembrane domain mutations regulating cytoskeletal functions. Cancer Res. 2003;63:6272-81.

87. Drilon A, Clark JW, Weiss J, et al. Antitumor activity of crizotinib in lung cancers harbouring a MET exon 14 alteration. Nat Med. 2020;26:47-51

88. Foundation medicine. Foundation medicine receives FDA approval for FoundationOne ${ }^{\oplus} \mathrm{CDx}$ as the companion diagnostic for TabrectaTM (capmatinib), the only FDA-approved MET inhibitor for patients with metastatic non-small cell lung cancer with METex14. 2020. Available at: www.foundationmedicine. com/press-releases/0f19426e-6c6b-4d75-8801-789b6f603eb2 (accessed January 14, 2021).

89. Paik PK, Felip E, Veillon R, et al. Tepotinib in non-small-cell lung cancer with MET exon 14 skipping mutations. N Eng/ J Med. 2020;33:931-43.

90. Illumina. Ampliseq for Illumina focus panel. 2020. Available at: www.illumina.com/products/by-type/sequencing-kits/libraryprep-kits/ampliseq-focus-panel.html (accessed January 21, 2021).

91. Archerdx. FusionPlex lung panel. 2020. Available at: https:// archerdx.com/research-products/solid-tumor-research/ fusionplex-lung/ (accessed January 14, 2021).

92. PR News Wire. ArcherDX's Companion Diagnostic Assay for both Liquid Biopsy and Tissue Specimens Granted Breakthrough Device Designation by U.S. Food and Drug Administration. 2019. Available at: www.prnewswire.com/news-releases/archerdxscompanion-diagnostic-assay-for-both-liquid-biopsy-and-tissuespecimens-granted-breakthrough-device-designation-by-usfood-and-drug-administration-300774247.html (accessed January 14, 2021)

93. Foundation Medicine. FoundationOne CDx. 2020. Available at: www.foundationmedicine.com/test/foundationone-cdx (accessed January 14,2021$)$

94. FDA. FoundationOne CDX - P170019. 2020. Available at: www.fda.gov/medical-devices/recently-approved-devices/ foundationone-cdx-p170019 (accessed January 14, 2021).

95. Thermo Fisher. Oncomine Focus Assay. 2020. Available at: www.thermofisher.com/uk/en/home/clinical/preclinicalcompanion-diagnostic-development/oncomine-oncology/ oncomine-focus-assay.html (accessed January 14, 2021). 96. Illumina. TruSight Oncology 500. 2020. Available at: www. illumina. $\mathrm{com} /$ products/by-type/clinical-research-products/trusightoncology-500.html (accessed January 14, 2021)

97. Archerdx. LiquidPlex ctDNA panel. 2020. Available at: https:// archerdx.com/research-products/solid-tumor-research/ liquidplex/ (accessed January 14, 2021).

98. Foundation Medicine. FoundationOne liquid. 2020. Available at: www.foundationmedicine.com/test/foundationone-liquid (accessed January 14, 2021)

99. Guardant 360. Guardant360 liquid biopsy. 2020. Available at: https://guardant360.com/ (accessed January 14, 2021).

100. US Food and Drug Administration. FDA Approves First Liquid Biopsy Next-Generation Sequencing Companion Diagnostic Test. 2020 Available at: www.fda.gov/news-events/press-announcements/ fda-approves-first-liquid-biopsy-next-generation-sequencingcompanion-diagnostic-test (accessed January 14, 2021).

01. PGDX. PlasmaSELECTTM 64. 2020. Available at: www. personalgenome.com/cap-clia (accessed January 14, 2021)

102. Sabari JK, Leonardi GC, Shu CA, et al. PD-L1 expression, tumour mutational burden, and response to immunotherapy in patients with MET exon 14 altered lung cancers. Ann Oncol. 2018:29:2085-91.

103. Mazieres J, Drilon A, Lusque A, et al. Immune checkpoint inhibitors for patients with advanced lung cancer and oncogenic driver alterations: results from the IMMUNOTARGET registry. Ann Oncol. 2019;30:1321-8.

104. Ma Y, Zhang M, Wang J, et al. High-affinity human anti-c-Met IgG conjugated to oxaliplatin as targeted chemotherapy for hepatocellular carcinoma. Front Oncol. 2019:9:717.

105. Reungwetwattana T, Liang Y, Zhu V, Ou S-HI. The race to target MET exon 14 skipping alterations in non-small cell lung cancer: The why, the how, the who, the unknown, and the inevitable. Lung Cancer. 2017;103:27-37.

106. Awad MM, Leonardi GC, Kravets S, et al. Impact of MET inhibitors on survival among patients with non-small cell lung cancer harbouring MET exon 14 mutations: a retrospective analysis. Lung Cancer. 2019;133:96-102.

107. Paik PK, Drilon A, Fan P-D, et al. Response to MET inhibitors in patients with stage IV lung adenocarcinomas harboring mutations causing exon 14 skipping. Cancer Discov. 2015;5:842-9.

108. Wolf J, Seto T, Han J-Y, et al. Results of the GEOMETRY mono-1 phase II study for evaluation of the MET inhibitor capmatinib (INC280) in patients (pts) with METAex14 mutated advanced nonsmall cell lung cancer (NSCLC). Ann Oncol. 2018;29:viii741-2.

109. Engstrom LD, Aranda R, Lee M, et al. Glesatinib exhibits antitumor activity in lung cancer models and patients harboring exon 14 mutations and overcomes mutation-mediated resistance to type I MET inhibitors in nonclinical models. Clin Cancer Res. 2017;23:6661-72

110. Vijayan RSK, He P, Modi V, et al. Conformational analysis of the DFG-out kinase motif and biochemical profiling of structurally validated type II inhibitors. J Med Chem. 2015;58:466-79.

111. Ou S-HI, Kwak EL, Siwak-Tapp C, et al. Activity of crizotinib (PF02341066), a dual mesenchymal-epithelial transition (MET) and anaplastic lymphoma kinase (ALK) inhibitor, in a non-small cell lung cancer patient with de novo MET amplification. J Thorac Oncol. 2011;6:942-6.

112. Shaw AT, Ou S-HI, Bang Y-J, et al. Crizotinib in ROS1-rearranged non-small-cell lung cancer. N Eng/ J Med. 2014;371:1963-71.

113. Tanizaki J, Okamoto I, Okamoto K, et al. MET tyrosine kinase inhibitor crizotinib (PF-02341066) shows differential antitumor effects in non-small cell lung cancer according to MET alterations. I Thorac Oncol. 2011;6:1624-31.

114. Landi $L$, Chiari $R$, Tiseo $M$, et al. Crizotinib in deregulated or rearranged pre-treated non-small cell lung cancer (METROS): A phase II, prospective, multicenter, two-arms trial. Clin Cancer Res. 2019;25:7312-9.

115. Moro-Sibilot D, Cozic N, Pérol M, et al. Crizotinib in c-MET- or ROS1-positive NSCLC: results of the AcSé phase II trial. Ann Oncol. 2019;30:1985-91

116. Rotow JK, Woodard GA, Urisman A, et al. Pathologic complete response to neoadjuvant crizotinib in a lung adenocarcinoma patient with a MET exon 14 skipping mutation. Clin Lung Cancer. 2019;20:e137-41.

117. Wang SXY, Zhang BM, Wakelee HA, et al. Case series of ME exon 14 skipping mutation-positive non-small-cell lung cancers with response to crizotinib and cabozantinib. Anticancer Drugs. 2019;30:537-41.

118. Schöffski P, Gordon M, Smith DC, et al. Phase II randomised discontinuation trial of cabozantinib in patients with advanced solid tumours. Eur I Cancer. 2017:86:296-304.

19. Klempner SJ, Borghei A, Hakimian B, et al. Intracranial activity of cabozantinib in MET exon 14-positive NSCLC with brain metastases. J Thorac Oncol. 2017;12:152-6.

120. D'Arcangelo M, Tassinari D, De Marinis F, et al. Phase II single arm study of CABozantinib in non-small cell lung cancer patients with MET deregulation (CABinMET). J Thorac Oncol. 2019;14:S644.

121. Yan SB, Um SL, Peek VL, et al. MET-targeting antibody (emibetuzumab) and kinase inhibitor (merestinib) as single agent or in combination in a cancer model bearing MET exon 14 skipping. Invest New Drugs. 2018;36:536-44.

122. He AR, Cohen RB, Denlinger CS, et al. First-in-human phase study of merestinib, an oral multikinase inhibitor, in patients with advanced cancer. The Oncologist. 2019;24: e930-42.

123. Recondo G, Bahcall M, Spurr LF, et al. Molecular mechanisms of acquired resistance to MET tyrosine kinase inhibitors in patients with MET exon 14-mutant NSCLC. Clin Cancer Res.

2020;26:2615-25

124. Besterman JM, Fournel M, Dupont I, et al. Potent preclinical antitumor activity of MGCD265, an oral Met/VEGFR kinase inhibitor in phase II clinical development, in combination with taxanes or erlotinib. J Clin Oncol. 2010;28(Suppl.15):e13595.

125. Bazhenova L, Mehra R, Nagy T et al. Amethyst NSCLC trial: Phase 2, parallel-arm study of receptor tyrosine kinase (RTK) inhibitor, MGCD265 in patients with advanced or metastatic non-small cell lung cancer (NSCLC) with activating genetic alterations in mesenchymal-epithelial transition factor (MET) Ann Oncol. 2016;27:vi450.

126. Deng W, Zhai D, Rogers E, et al. TPX-0022, a polypharmacology inhibitor of MET/CSF1R/SRC inhibits tumour growth by promoting anti-tumour immune responses. Cancer Res. 2019:79(Suppl.13):1325

127. Hong D, Bazhenova L, Cho BC, et al. First-in-human safety, pharmacokinetics, and preliminary efficacy of TPX-0022, a nove inhibitor of MET/SRC/CSF1R in patients with advanced solid tumours harbouring genetic alterations in MET. Eur I Cancer. 2020;138:S1.

128. Baltschukat S, Engstler BS, Huang A, et al. Capmatinib (INC280) is active against models of non-small cell lung cancer and other cancer types with defined mechanisms of MET activation. Clin Cancer Res. 2019:25:3164-75.

129. Liu X, Wang Q, Yang G, et al. A novel kinase inhibitor, INCB28060, blocks C-MET-dependent signaling, neoplastic activities, and crosstalk with EGFR and HER-3. Clin Cancer Res. 2011;17:7127-38.

130. US Food \& Drug Administration. FDA grants accelerated approval to capmatinib for metastatic non-small cell lung cancer. 2020. Available at: www.fda.gov/drugs/drug-approvals-and-databases/ fda-grants-accelerated-approval-capmatinib-metastatic-nonsmall-cell-lung-cancer (accessed January 15, 2021).

131. Novartis. Novartis announces FDA approval of MET inhibitor Tabrecta $^{\mathrm{TM}}$ for metastatic non-small cell lung cancer with METex14. 2020. Available at: www.novartis.com/news/mediareleases/novartis-announces-fda-approval-met-inhibitor-tabrectametastatic-non-small-cell-lung-cancer-metex14 (accessed January 15,2021$)$

132. Wolf J, Seto T, Han J-Y, et al. Capmatinib in MET exon 14-mutated or MET-amplified non-small-cell lung cancer. N Eng/ J Med. 2020;383:944-57.

133. Vansteenkiste JF, Van De Kerkhove $C$, Wauters E, Van Mol P. Capmatinib for the treatment of non-small cell lung cancer. Expet Rev Anticancer Ther. 2019;19:659-71.

134. Bladt F, Faden B, Friese-Hamim M, et al. EMD 1214063 and EMD 1204831 constitute a new class of potent and highly selective c-Met inhibitors. Clin Cancer Res. 2013;19:2941-51.

135. Merck. TEPMETKO (Tepotinib) Approved in Japan for Advanced NSCLC with METex14 Skipping Alterations. Available at: www.emdgroup.com/en/news/tepotinib-25-03-2020.htm (accessed January 15, 2021)

136. Blanc-Durand F, Alameddine R, lafrate AJ, et al. Tepotinib efficacy in an NSCLC patient with brain metastasis harbouring an HLADRB1-MET gene fusion. Oncologist. 2020;25:916-20.

137. Jia H, Dai G, Weng J, et al. Discovery of (S)-1-(1-(Imidazo[1,2-a pyridin-6-yl)ethyl)-6-(1-methyl-1H-pyrazol-4-yl)-1H-[1,2,3] triazolo[4,5-b]pyrazine (Volitinib) as a highly potent and selective mesenchymal-epithelial transition factor (c-Met) inhibitor in clinical development for treatment of cancer. J Med Chem. 2014;57:7577-89.

138. Gavine PR, Ren Y, Han L, et al. Volitinib, a potent and highly selective c-Met inhibitor, effectively blocks c-Met signalling and growth in c-MET amplified gastric cancer patient-derived tumour xenograft models. Mol Oncol. 2015:9:323-33.

139. Lu S, Fang J, Li X, et al. Phase II study of savolitinib in patients (pts) with pulmonary sarcomatoid carcinoma (PSC) and othe types of non-small cell lung cancer (NSCLC) harbouring MET exon 14 skipping mutations (METex14+). I Clin Oncol. 2020;38(Suppl. 15):9519

140. Shih J, Zhong B, Shi H, et al. Bozitinib, a highly selective inhibitor of cMet, demonstrates robust activity in gastric, lung, hepatic and pancreatic in vivo models. Cancer Res. 2017;77(Suppl.13):2096.

141. Hu H, Mu Q, Bao Z, et al. Mutational landscape of secondary glioblastoma guides MET-targeted trial in brain tumor. Cell. 2018;175:1665-78

142. Ai J, Chen Y, Peng X, et al. Preclinical evaluation of SCC244 (glumetinib), a novel, potent, and highly selective inhibitor of c-Met in MET-dependent cancer models. Mol Cancer Ther. 2018;17:751-62

143. Liu L, Zeng W, Wortinger MA, et al. LY2875358, a neutralizing and internalizing anti-MET bivalent antibody inhibits HGF-dependent and HGF-independent MET activation and tumor growth. Clin Cancer Res. 2014;20:6059-70.

144. Banck MS, Chugh R, Natale RB, et al. Phase 1 results of emibetuzumab (LY2875358), a bivalent MET antibody, in patients with advanced castration-resistant prostate cancer, and MET positive renal cell carcinoma, non-small cell lung cancer, and hepatocellular carcinoma. Mol Cancer Ther. 2015;14(Suppl.2):A55

145. Spigel DR, Edelman MJ, O'Byrne K, et al. Results from the phase III randomized trial of onartuzumab plus erlotinib versus erlotinib in previously treated stage IIIB or IV non-small-cell lung cancer: METLung. J Clin Oncol. 2016;35:412-20.

146. Poulsen TT, Grandal MM, Skartved NJØ, et al. Sym015: A highly efficacious antibody mixture against amplified tumors. Clin Cancer Res. 2017;23:5923-35.

147. Camidge DR, Janku F, Martinez-Bueno A, et al. Safety and preliminary clinical activity of the MET antibody mixture, Sym015 
MET amplification/exon 14 deletion (METAmp/Ex14A). J Clin Oncol. 2020;38(Suppl.15):9510

148. DaSilva JO, Yang K, Perez Bay AE, et al. A biparatopic antibody that modulates MET trafficking exhibits enhanced efficacy compared with parental antibodies in MET-driven tumor models. Clin Cancer Res. 2020;26:1408-19.

149. Rowlands T, Boyapati A, Li S, et al. A phase I//l study of REGN5093, a MET X MET bispecific antibody, in patients with MET-altered advanced non-small cell lung cancer (NSCLC). J Clin Oncol. 2020;38(Suppl.15): TPS9628

150. Camidge DR, Barlesi F, Goldman JW, et al. Results of the phase 1b study of ABBV-399 (telisotuzumab vedotin; teliso-v) in combination with erlotinib in patients with c-Met+ nonsmall cell lung cancer by EGFR mutation status. J Clin Oncol. 2019:37(Suppl.15):3011.

151. Strickler JH, Weekes CD, Nemunaitis J, et al. First-in-human phase I, dose-escalation and -expansion study of telisotuzumab vedotin, an antibody-drug conjugate targeting c-Met, in patients with advanced solid tumors. J Clin Oncol. 2018;36:3298-306.

152. Middleton G, Fletcher P, Popat S, et al. The National Lung Matrix Trial of personalized therapy in lung cancer. Nature. 2020;583:807-12.

153. Bang Y-J, Su W-C, Nam D-H, et al. Phase I study of the safety and efficacy of INC280 in patients with advanced MET-dependent solid tumours. J Clin Oncol. 2014;32(Suppl.15):2520.

154. Schuler M, Berardi R, Lim W-T, et al. Molecular correlates of response to capmatinib in advanced non-small-cell lung cancer: clinical and biomarker results from a phase I trial. Ann Oncol. 2020;31:789-97.

155. Wolf J, Seto T, Han J-Y, et al. Capmatinib (INC280) in MET $\triangle$ ex14mutated advanced non-small cell lung cancer (NSCLC): Efficacy data from the phase II GEOMETRY mono-1 study. J Clin Oncol. 2019;37(Suppl.15):9004

156. Heist RS, Garon EB, Tan DSW, et al. Biomarker analysis of patients with MET $\triangle$ ex14 mutated non-small-cell lung cancer (NSCLC) treated with capmatinib in the GEOMETRY mono-1 study. MOl Canc Ther. 2019;18(Suppl.12):A029.

157. Awad MM, Lee JK, Madison R, et al. Characterization of 1,387 NSCLCS with MET exon 14 (METex14) skipping alterations (SA) and potential acquired resistance (AR) mechanisms. J Clin Oncol. 2020;38(Suppl.15):9511

158. Ou S-HI, Young L, Schrock AB, et al. Emergence of preexisting MET $\mathrm{Y} 1230 \mathrm{C}$ mutation as a resistance mechanism to crizotinib in NSCLC with MET exon 14 skipping. J Thorac Oncol. 2017;12:137-40.

159. Schrock AB, Lai A, Ali SM, et al. Mutation of MET Y1230 as an acquired mechanism of crizotinib resistance in NSCLC with MET exon 14 skipping. J Thorac Oncol. 2017;12:e89-90.

160. Fujino T, Kobayashi Y, Suda K, et al. Sensitivity and resistance of MET exon 14 mutations in lung cancer to eight MET tyrosine kinase inhibitors in vitro. J Thorac Oncol. 2019:14:1753-65.

161. Suzawa K, Offin M, Schoenfeld AJ, et al. Acquired MET exon 14 alteration drives secondary resistance to epidermal growth factor receptor tyrosine kinase inhibitor in EGFR-mutated lung cancer. JCO Precis Oncol. 2019;3:10.1200/PO.19.00011.

162. Jamme P, Fernandes $\mathrm{M}$, Copin $\mathrm{M}$-C, et al. Alterations in the PI3K pathway drive resistance to MET inhibitors in NSCLC harboring MET exon 14 skipping mutations. J Thorac Oncol. 2020;15:741-51.

163. Guo R, Offin M, Brannon AR, et al. MET inhibitor resistance in patients with MET exon 14-altered lung cancers. I Clin Oncol. 2019;37(Suppl.15):9006

164. Rotow JK, Gui P, Wu W, et al. Co-occurring alterations in the RASMAPK pathway limit response to MET inhibitor treatment in MET exon 14 skipping mutation-positive lung cancer. Clin Cancer Res. 2020;26:439-49.

165. Fujino T, Suda K, Mitsudomi T. Emerging MET tyrosine kinase inhibitors for the treatment of non-small cell lung cancer. Expet Opin Emerg Drugs. 2020;25:229-49. 